International Journal of Social Sciences and Humanities
Available online at http://sciencescholar.us/journal/index.php/ijssh
Vol. 2 No. 2, August 2018, pages: $1 \sim 14$
e-ISSN: 2550-7001, p-ISSN: 2550-701X
http://dx.doi.org/10.29332/ijssh.v2n2.112

\title{
Yoga as Lifestyle of Postmodern Society in Bintaro Jaya
}

\begin{abstract}
CrossMark

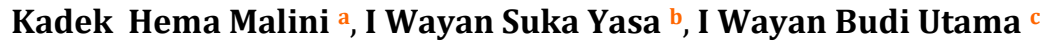

Article history: Received 9 August 2017, Accepted in revised form 1 March 2018, Approved 17 April 2018, Available online 27 April 2018

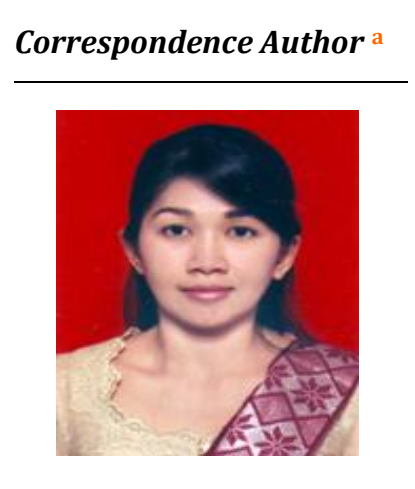

Keywords

Cultural trend;

Lifestyle;

Postmodern society;

Postmodern;

Practice yoga;

Abstract

Yoga is becoming a cultural trend that evolves into a mass culture. The most people, especially in the big cities, practice yoga. It means that yoga becomes popular even more with the role of mass media. Therefore, making yoga as a lifestyle in postmodern society. The popularity of yoga brings the changes impact for the yoga teachings. Regarding the teachings that were originally sacred into profane cultural products. There is a profane transformation of the yoga practice that demonstrates the ideological indoctrination for the purpose of capitalism in the yoga culture industry. It was intended to meet the needs and social satisfaction. It was marked the compromise to the market through commercial cultural products. Thus, yoga products were easily accepted by the public. This could be seen from the emergence of yoga genres that varied and have undergone modification and massification of interest and increase the interest of the audience. Therefore, becoming expand the market share of yoga practices whose goal was to gain profit. There were also classes of teacher training as the impact of this culture industry. It made yoga practices that were originally a purely cultural product transformed into a commodity to generate profits. Yoga teaching was no longer considered a sacred product of spirituality, however, it could also be exploited for the benefit of the market for profit.
\end{abstract}

e-ISSN : 2550-7001, p-ISSN : 2550-701X ๑ Copyright 2018. The Author. SS Journals Published by Universidad Técnica de Manabí. This is an open-access article under the CC BY-SA 4.0 license

(https://creativecommons.org/licenses/by-sa/4.0/) All rights reserved.

\section{Contents}

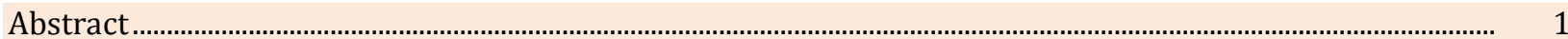

1. Introduction

Background of yoga changes from sacred belief system becomes a lifestyle .........................................................

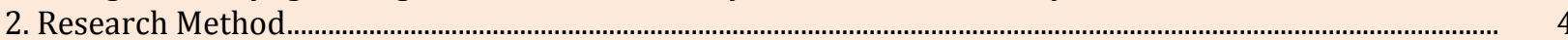

a STA Dharma Nusantara Jakarta, Indonesia

b University of Hindu Indonesia, Indonesia

c University of Hindu Indonesia, Indonesia 


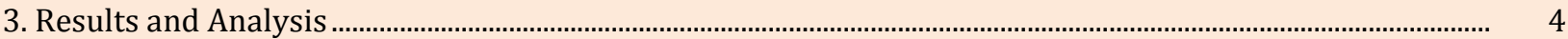

3.1 Yoga practice varieties towards postmodern society …..................................................................................

3.2 Yoga development implications of the sacred belief system become lifestyle ................................................... 5

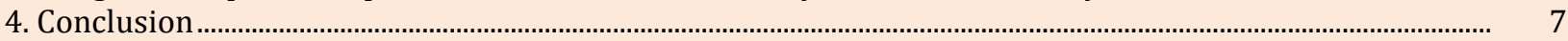

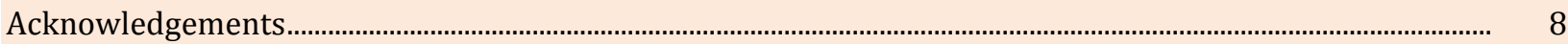

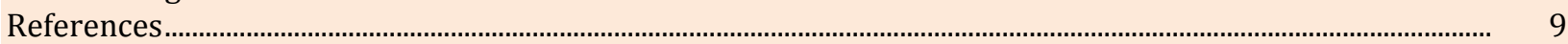

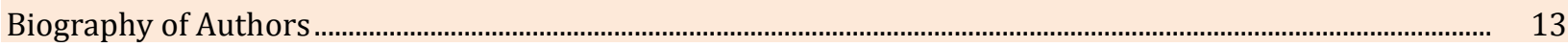

\section{Introduction}

The practice of yoga is becoming a popular culture currently producing mass culture among the wider society. The practice of mass yoga is widely featured in both national and international events involving hundreds or even thousands of participants by inviting well-known instructors sponsored by big companies. It is also common in fitness club that is usually located in strategic places e.g., shopping centers, malls, shops, offices or studios located in residential areas. Moreover, the most interesting is the yoga genre with various benefits and purposes, included Hot Yoga, Detox Yoga, Floating Yoga, Yoga for Slim, Prenatal Yoga, and many other types of yoga are increasingly famous in accordance with market demand.

The practice of yoga is conducted depends on the daily activities of postmodern society from all professions either having an occupation as office workers, businessmen who have the more flexible time or housewife. It means that daily activity determines when yoga practice is done is not the appropriate time that determines when yoga should be done. The teachings of yoga, known in Hinduism, are performed in quiet places that can provide the vibrations of sanctity e.g., forests, mountains, riversides, beaches, ashrams in order to assist in the process of mind control and concentration, nowadays in places provide convenience, comfort, and even prestige value for the society. They like fitness places that are fitness center which is usually located in the mall or shopping center or yoga art studio in the office.

Referring to the true meaning of the yoga teachings as a sacred teaching in the Hindu Philosophy system wherein its application is done by reciting the mantra with the aim of purification and silence and concentration of mind undergoing a change into a popular lifestyle for society especially for upper-middleclass society. The yoga practice today undergoes a change in its application either by removing or adding some parts in the process. Therefore, it implies causing a shift in practice, purpose, and meaning to the actual yoga practice.

\section{Background of yoga changes from sacred belief system becomes a lifestyle}

For the first yoga was introduced to the West by Svami Vivekananda in the nineteenth and early twentieth centuries followed by other yogic teachers from India. The holy teachers, unlike Yogananda Paramahamsa, Maha Rsi Mahesh Yogi, Maharsi Iyengar, Baba Ramdev, Sri Ravi Shankar and others. Yoga then became very popular in the West in the 1980s but more commonly known as a system of physical exercise (White in Suwantana, 2016: 145). The popularity of yoga brings influence to the change of yoga teachings of the sacred belief system become lifestyle due to the following factors.

a) Society awareness towards healthy

Increasing the society awareness for their health makes the yoga asanas practice an option to improve the quality of life by achieving a balance of physical and spiritual health. Yoga is chosen as a way to obtain a healthy body with simple and visible side effects. By practicing yoga, various benefits can be obtained unlike, is able to nourish the physical body, maintain body balance, improve posture, improve the body's immune system and cure diseases, accelerate detoxification and can control emotions and relieve stress.

".yogasana is also conducted slowly with relaxation and concentration. In this way, both the external and internal system will be affected, therefore, the nervous system, endocrine glands, and internal organs, as well as the muscles, are encouraged to function well. Thus, the asana has a physical and psychological influence that is useful in curing diseases "(Sarasvati, 2002: 3). 
The efforts to practice Hatha Yoga completely and perfectly, asanas or breathing exercises or pranayama in addition to the practice of purifying thoughts and feelings through dhyana yoga causes a process of awareness raising. In addition, also the understanding of soul creativity into the spirit that will provide support to physical and spiritual health (Buanadjaya, 2005: 14).

b) Lifestyle

Yoga trends are inseparable from the concept of openness in the social life. Unlike, Chaney explained that the development of lifestyle and the structural change of modernity are interconnected through institutional reflectivity, i.e., "due to the openness" of contemporary social life, the pluralization of action context and various authority. The lifestyle choice is increasingly important in the preparation of self-identity and daily activities.Yoga as lifestyle can not be separated from the change of meaning in postmodern society as the lifestyle century. In this case, the appearance of self esthetics, even body/self is experiencing body aesthetics. The body/self and everyday life become a project, the seed of lifestyle seeding. "You are stylish then you exist" is a very suitable phrase to describe the fondness of the style for postmodern society (Chaney, 2006: 15).

The human desires are essentially limited (Deleauze \& Gauttari in Hartono, 2007: 121). The real human is the human who pursues the desire for the ultimate inner originality every time. The passionate human body is what makes capitalism more creative to defend its interests. Playing with the artificial needs of desire based on the workings of advertising agencies, technology, liberal economic, bureaucracy, and economic and cultural frontiers, one's desires are easily infected by consumptive viruses (Raditya 2014: 68). A capitalism always strings ways to satisfy the deepest desires of the human. The desired basis is a pleasure, comfort, and endless sensation. The various needs of desire will be engineered with the principle of endless shortcomings (Pilliang in Adlin, 2006).

The yoga practice is popular as a manifestation of the desired attainment. Yoga is packaged as a cultural product that not only can produce benefits in practicing yoga. However, it is also able to provide the desire satisfaction for pleasure and comfort. In addition, it can also relate the social life of the yoga actor. The yoga practice is also interpreted as a symbolic act to show their identity in their social environment in which the character of the society prefers the look that everyone wants to present themselves in front of others to be watched and to watch. Yoga is packaged as a cultural product that not only can produce benefits in practicing yoga.

c) Consumer culture

The consumption rationality in the consumption-society system has changed considerably. This change occurs due to the people buy goods, not as an attempt to meet their needs. However, unlike the desire fulfillment. The consumption society will buy symbols attached to an object. Therefore, many consumption objects are eroded its use and its exchange values. A symbolic value then becomes a commodity. To be the consumption object must have a sign. It happens because only it can be personalized and consumed objects (Martono, 2014: 95).

The society lifestyle itself has implications for consumption power. The society does not only consume something based on the value of use but also turns into consumer, which is to consume something other than to spend the value of use. Due to the symbolic value (social status and prestige), namely self-image for the appearance of good looking by others (Piliang, 179: 2006). Baudrillard (2006) stated that each individual's consumption ability is different, each society undergoes differentiation, social discrimination (in Martono, 2014: 91). Without realizing the emergence of exclusive yoga classes gave birth to social differentiation in the level of yoga actors themselves are triggered consumptives. A consumption expresses the social position and cultural identity of a person within society, that is consumed no longer merely an object but also the hidden social meanings behind it. A self-image as a form of self-expression to show its identity in the social environment resulting in social differentiation in practicing yoga due to the ability of each individual consumption is different.

In the Consumer Society, Baudrillard (2006) analogized consumption to contemporary societies with language and sign systems. Throughout, the humanity requires a symbol that is worshiped and prayed. If there used to be a tree or a statue, nowadays, the society also has its own cults, unlike the objects packaging, images, and television (Baudrillard in Haryanto, 2012: 310). It is called a 
simulation that encourages the emergence of hyper-reality that makes this modern society become excessive in the pattern of eating something that is not the clear essence. The most people consume not because of their economic needs, but because of the influence of simulation models that cause people's lifestyles to be different. They become more concerned with their lifestyles and values that are held in high esteem (Jhon, 2001: 35).

d) Mass media as a new cultural mediator

The mass culture trend is not separated from Baudrillard opinion as a simulation with the main vehicle is advertising. In this case, the media holds a mirror, therefore, as reflection broadly enough a social reality. Media plays a role in constructing both our sense of the social reality and our sense of being part of the social reality (Currant, Bennet in Strinati, 2016: 274).

Yoga became a trendsetter in terms of lifestyle for postmodern society. Strinati viewed produced through mass production industrial techniques and marketed to benefit the mass consumer audiences supported by media intermediaries. The role of mass media, especially, advertising as a tool indoctrination sophisticated and systematic in providing understanding to the society and invite the society to participate in practicing yoga activities. Imagination is illustrated by the mass media raising of consumerism practices by making the body as a living capital to show the prestige and social identity. Therefore, the market with the mechanism of production and media imaging make Yoga Asana as the middle-class lifestyle in the city.

In terms of yoga practices, advertising plays a significant role to maintain interest for yoga audience. Some efforts are taken. One of them is carrying out yoga practices performed on certain moments that support the purpose and benefits of the yoga practice. Various propaganda in terms of yoga activities is not uncommonly conducted in mass and open to the public. The society is treated to all the information about yoga, either through print, electronic, and banner advertisements of many yoga courses scattered in strategic places. In addition, there are also advertisements in gyms and fitness centers that organize yoga, e.g., studio or yoga studio more often through social media. The ads are not only show the lifestyle but also naturalize it. When ads that appear and are repeatedly sung and repeatedly will gradually give its consumers a form of false consciousness to their customers. It makes as if the advertised thing becomes a natural truth (Abdullah, 2009: 118).

\section{Research Method}

The present study is used a qualitative method. Therefore, the analysis is conducted by paraphrasing in order to provide a brief exploration regarding the yoga existence as a lifestyle in the postmodern society. It is a library research that is supported by some theories as well as the phenomenologist that is happened in this era. Data collection is obtained by observation, interview, and document study.

\section{Results and Analysis}

\subsection{Yoga practice varieties towards postmodern society}

Yoga classes that appear unlike Kapha Yoga, Hot Yoga, Gentle Yoga and others are a commodification process in Hatha Yoga. The yoga genre that emerges as a form of capitalism in maintaining specialization market in the yoga practice. The new yoga classes are introduced with a new name, a modified posture of asanas postures, a new place and new fixtures that accompany it. Therefore, the society remains interested and challenged to try the yoga practice. For industries that engage in yoga practice, producing new products in the form of a new yoga class aims to keep society interested. Therefore, they still have a high selling point by reaching the widest possible market share in order to gain profit. Barker (2006) defined commodification as an association process of capitalism, i.e., objects, qualities, and marks serve as commodities (Piliang in Barker, 2000:).

The change of name or term in asanas postures that originally used the Sanskrit name or language to be a name in English language or animal or object in the posture itself. Unlike, Parvatasana is called down face single, Sirsasana called headstand and others aim to make it easier to remember for the general society. Due to asanas postures in Sanskrit are considered very difficult to remember because of unfamiliar language. Unlike, the case if using English or Indonesian language will be easier to understand the postures requested by the instructor to be practiced. The removal or alteration of Sanskrit names into English, 
Indonesian or other symbolic terms in various postures of yoga is an attempt to transform the propagation of yoga practices that show the ideological indoctrination for the purpose of capitalism in the yoga culture industry. It aims to meet the social needs and satisfaction, which marked the compromise to the market through commercial cultural products. Thus, yoga products are easily accepted by the society.

The wide range of activities that arise related to yoga practices is an effort to keep consumers is a way that Chaney refers to as a very creative form of reflection in bringing the market to meet their needs and satisfaction. It is marked by a compromise to the market through commercial cultural products for the purpose of earning a profit. Yoga as a popular culture makes this cultural industry producing various types of related cultural production or related to yoga is a form of mechanism that modifies the distribution and use of its products. Various cultural productions emerging from yoga varieties such as yoga retreat, yoga contents, yoga fair is an effort to keep consumers captive to keep the market focused on the yoga practice. The variety of yoga practices is a form of cultural production in the yoga industry that is manufactured that treats the consumer as the objective production.

\subsection{Yoga development implications of the sacred belief system become lifestyle}

a) Yoga as a popular culture became beginning of mass culture emergence

Yoga popularity spans the distance is not short. Since yoga was first introduced by Svami Vivekananda and followed by Rsi Paramahamsa et. al in America has brought the yoga practice into a lifestyle of the world society. In addition, it also shows its existence in the last ten years. The long yoga span as a popular culture has implications for many aspects that drive it. Yoga as a popular culture moves indefinitely to a culture, it is called a mass culture (Bungin, 2009: 77-78). Yoga is nontraditional and generally, yoga activities are supported by mass communication that is closely related to the event of infotainment or entertainment. A mass communication in yoga activities has an important and effective role to influence cultural behavior and homogeneity in society. Mass communication is used as a container for marketing and advertising goals. In addition, the cultural products are increasingly developed and reconstructed according to emotion and feeling image to bring public interest to them. The nature of capitalism brings society into mass, meaning that society is melted from its traditional boundaries into one massive consumption (Strinati, 2016: xv).

The yoga practice is non-traditional, religious, and cultural barriers are driven by mass communication resulting in mass yoga practices. Yoga as a popular culture creates mass culture products that are constantly being reproduced and mass-produced. Therefore, the industries created from mass culture are oriented towards creation to gain the most profit in the consumer audience. Yoga as a mass culture is also produced exclusively using class symbols. Thus, it seems destined to a homogeneous, limited, and closed modern society.

b) Popular culture industries in yoga practice

Adorno and Horkheimer (1979) in his article entitled The Culture Industry Enlightenment as Mass Deception criticized that commodification occurs due to cultural industries development. It can be seen from various products produced by popular culture. In this sense, a pop culture has the purpose to be sold or marketed, therefore, unlike to profit as much as possible. No doubt, what is sought is profit through market mechanisms in the form of demand and supply.

According to Bataille (2006), the capitalist society seeks to channel the mandate part into full economic growth to bring about endless growth (in Featherstone, 2008: 50). The capitalism gives rise to images and places of consumption that support excessive enjoyment. An image and places that support obfuscation of original boundaries of the culture. Increased interest in yoga was caught as an opportunity for industry engaged in the yoga practice to further introduce, develop and expand interest in yoga for audiences. It makes the yoga practice of changing from purely cultural production into a commodity whose goal is to gain profit. Yoga teaching is no longer considered a sacred product of spirituality, but can also be exploited for the market interests. Various products of yoga classes appear and developed in accordance with market interest, therefore, the new types of yoga appear increasingly varied. Yoga as a popular culture creates mass culture products that are constantly being reproduced and mass-produced. Thus, the industries created from this mass culture are oriented towards creation to gain the most profit in the consumer audience. Yoga practices undergo a process of modification and massification. This modification

Malini, K., Yasa, I., \& Utama, I. (2018). Yoga as lifestyle of postmodern society in Bintaro Jaya. International Journal Of Social Sciences And Humanities (IJSSH), 2(2), 1-14. doi:10.29332/ijssh.v2n2.112 
is conducted by changing some, even almost all cultures to be more commercial or mastering the high selling value that aims to attract interest.

The yoga trend mass with the theme of tourism and entertainment in accordance with Baudrillard viewed, in his book entitled Ectasy of Comunication (1987). It is described that the meaning, information, and society transparency has exceeded the threshold to permanent ecstasy (Ibrahim, 1996: xvii). In the midst of the world of things, society, bodies, and information are included in an area that does not escape the intervention of economic logic. The people's logic who want to always look 'over' in terms of the style of finding channels through the pop culture industry. Thus, in its growth this culture has helped to construct a society, that is, its lifestyle is cultured and adored. Unlike Adorno (2006) pointed out that cultural phenomena serve as a form of 'social glue' and put people on the lived realities. The production and consumption of culture in capitalist society is inevitably standardized. However, the standardization is not only ignored the difference between meaning and function, but it also can not be known how far the culture is standardized (Strinatri, 2014: 93).

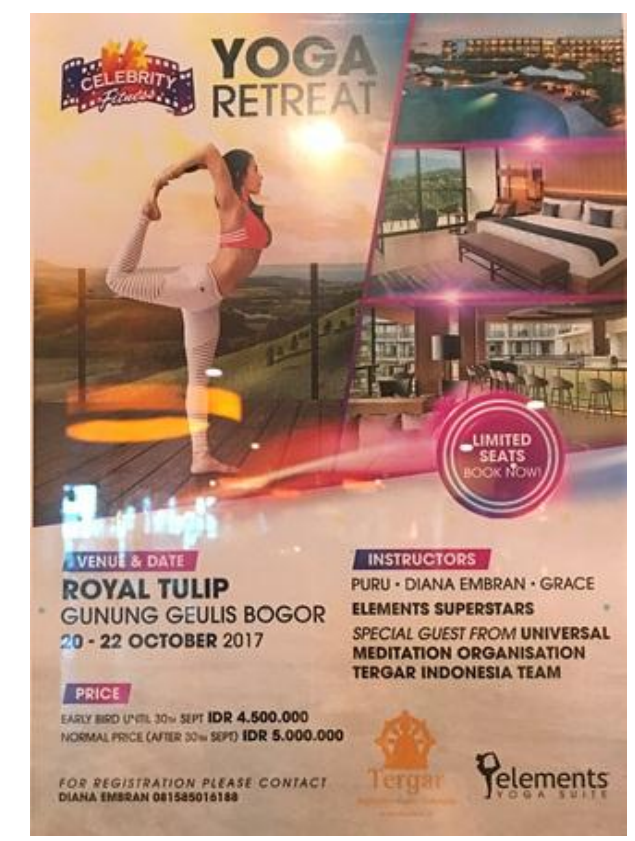

Figure 1. Workshop Detox Yoga

Source: Web Celebrity Fitness, 2017

According to Adorno (2006), in the emerging capitalism emerges the moral issues caused by consumer engineering through commodities. Popular culture or commodity culture is a way of manipulating society through a form namely total administration that is a mass regulation element (consumer) from above (producer), thus, to make society as a passive mass. The society tastes are governed by the producers through certain standardization to make them a mute masses and vice versa, affirming the existing dominant order to production and ideology (bourgeois ideology) (Piliang, 2006: 190). The popular culture supported by the culture industry has constructed a society that is not simply consumption-based but also makes all cultures an industrial product called commodities. It raises a new image for the society, commodity society that breeds pop culture and imposes worship, pray, and cult ectasy lifestyle.

a) Body capitalization in yoga practice

The body, in this case, becomes a capitalism commodity as a pillar buffer of mass consumption through various commodity production related to yoga practices. Various descriptions of benefits accompanied by the results lure to be achieved by practicing yoga plural seen in various discourses and media. In the capitalist realm, there is extreme objectivism of the body, thus, the body is a commodity equivalent to the other commodities objects. The body is converted as a sign and image that is loaded with certain concepts, themes, and meanings. From the benefits of maintaining body fitness, flexing the body, 
eliminating illness, slimming the body, make ageless, increase fertility, conducted labor well process to increase stamina in the sexual life into jargon in some yoga products.

In the capitalist world, the body becomes a kind of raw material in the capitalism sign exchange system. Accordingly, the body is processed, polished, packaged, manipulated, and engineered in order to produce a charm that produces commodity images. The strength of the body within the culture of capitalism lies in its 'seduction' power, its ability to freely play its markings into a 'system of seduction' of advanced capitalist society. The seduction works through an appearance, the sensible world game and the body signs that build it (Raditya, 2014: 99).

The body is loaded with the certain concepts, themes, and meanings as a way of creating a partition, segmentation, and social differentiation by creating social differences related to the body. Body marks and images are constructed in the media to place the body in a semiotic differentiation system. It aims to create the attraction and pleasure of seeing commodities. The body has no longer the function of cast or subject in this practice but turns into a commodity object that aims to gain profit. Unlike in Yoga Detox.

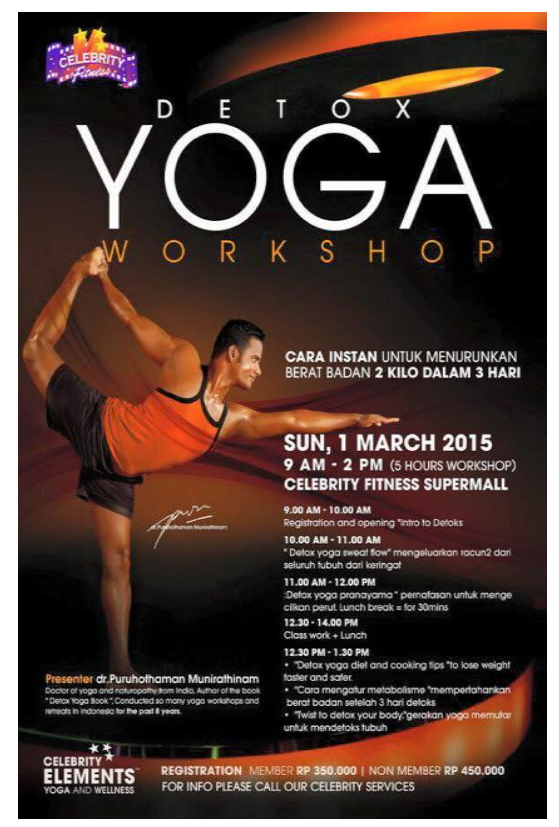

Figure 2. Workshop Detox Yoga

Source: Web Celebrity Fitness, 2015

The slogan is "an instant way of decreasing two kilograms in three days." This product constructs a social perspective that everyone can get the desired weight through yoga detox. In capitalism, it can be stated that the body is subjected to exploitation for the motive of capital and profit rotation.

b) Religious implications

Yoga that should be practiced is yoga for spiritual purposes, namely through the seven stages of Ashtanga Yoga. However, nowadays, the yoga practices precisely eliminates the spiritual aspects contained in pratyahara, dharana, dhyana, and samadhi stages. Due to the loss of the yoga essence as a spiritual path to deliverance. Yoga is practiced is a yoga practice that has been affected by the culture industry that makes yoga practiced today is packed with postmodern culture is with all forms of comfort and entertainment facilities that make the yoga practice as one form of physical exercise. It can be entertained in such a way which aims to attract consumers, therefore, to expand the market share for profit.

c) Cultural implications

Hatha Yoga as a new culture for postmodern society is able to penetrate cultural barriers in all circles without seeing the hierarchy in the society. Therefore, yoga is accepted and quickly expanded in all life

Malini, K., Yasa, I., \& Utama, I. (2018). Yoga as lifestyle of postmodern society in Bintaro Jaya. International Journal Of Social Sciences And Humanities (IJSSH), 2(2), 1-14. doi:10.29332/ijssh.v2n2.112 
which implies the emergence of sophisticated ideological indoctrination by using entertainment to sweeten the rise of cultural hegemony gradually undermining cultural standards in the practice of Hatha Yoga. The goal is to suppress any form of expression that defies the existing order. The presence of industrial products is a more massive culture will bring up the repressive and tend to fool. It can mask people's understanding of the true yoga teachings.

\section{Conclusion}

The lifestyle society nowadays indirectly influences the emergence of the culture industry in the yoga practice. It is coupled to media support, the yoga practice became a commercial culture that gave rise to massive ectasy through the society consumptive culture in the postmodern era that had implications for the society hedonism culture. It obscures the principle of the meaning and usefulness of the yoga practice itself with the exchange principle in the form of goods and entertainment that produces propagation on yoga practices with the aim to gain profit.

\section{Acknowledgments}

The authors say thanks to the managers of the gymnasium in Bintaro area, STAH Dharma Nusantara Jakarta, and Postgraduate in UNHI Denpasar. 


\section{References}

1) Abdullah, I., Wening, U., \& Hasse, J. (2009). Dinamika Masyarakat dan Kebudayaan Kontemporer. Yogyakarta: Tici Publications Bekerjasama Pustaka Pelajar.

View in (Google Scholar)

2) Acarya, Avadhutika Anandamitra. (1990). Yoga untuk Kesehatan Latihan 8 Yoga Ananda Marga. Jakarta: Ananda Marga Publications.

View in (Google Scholar)

3) Agung, I Gusti Ngurah. (2016). Prosiding Seminar Nasional Kemanfaatan Latihan Fisik dalam Meningkatkan Kesehatan Jasmani dan Rohani Menuju Kesempurnaan Hidup. Denpasar : IHDN.

View in (Google Scholar)

4) Asli, Luh. (2016). Prosiding Seminar Nasional Kemanfaatan Latihan Fisik Dalam Meningkatkan Kesehatan Jasmani dan Rohani Menuju Kesempurnaan Hidup. Denpasar: IHDN.

View in (Google Scholar)

5) Asmariani, Anak Agung Raka. (2016). Prosiding Seminar Nasional Kemanfaatan Latihan Fisik Dalam Meningkatkan Kesehatan Jasmani dan Rohani Menuju Kesempurnaan Hidup. Denpasar : IHDN.

View in (Google)

6) Barker, C. (2004). Cultural Studies: Teori \& Praktik. Kreasi Wacana.

View in (Google Scholar)

7) Tarigan, M. (2016). Nilai-nilai sufistik dalam syāir-syāir Hamzah Fansuri (analisis tematik kitab asrĀru'l 'Ārifin(Doctoral dissertation, Pascasarjana UIN Sumatera Utara).

View in (Google Scholar)

8) Burton, G. (2012). Media dan budaya popular. Jalasutra.

View in (Google Scholar)

9) Graeme, B. (1999). Pengantar untuk Memahami Media dan Budaya Populer.

View in (Google Scholar)

10) Chaney, D. (1996). Lifestyles: sebuah pengantar komprehensif. Yogyakarta: Jalasutra.

View in (Google Scholar)

11) Evans, D. S. \& P. (2004). Das Kapital untuk Pemula. Yogjakarta: Resist Book.

View in (Google)

12) Featherstone, M. (2008). Posmodernisme dan Budaya Konsumen (Consumer Culture and Posmodern). Terjemahan). Yogyakarta: Pustaka Pelajar.

View in (Google Scholar)

13) Hariyanto, H. (2009). Dakwah STAIN Purwokerto Komunika ISSN: 1978-1261 Vol. 3 No. 2 Juli-Desember 2009 pp. 167-183 gender dalam konstruksi media. komunika: Jurnal Dakwah dan Komunikasi, 3(2), 167183.

View in (Google Scholar)

14) Hartono, Ahustinus. (2007). Geneologi Hasrat Deleauze \& Gauttari. Yogyakarta : Jalasutra. View in (Google Scholar)

Malini, K., Yasa, I., \& Utama, I. (2018). Yoga as lifestyle of postmodern society in Bintaro Jaya. International Journal Of Social Sciences And Humanities (IJSSH), 2(2), 1-14. doi:10.29332/ijssh.v2n2.112 
15) Harvey, D. (2012). From space to place and back again: Reflections on the condition of postmodernity. In Mapping the futures (pp. 17-44). Routledge.

View in (Google Scholar)

16) Haryanto, S. (2012). Spektrum Teori Sosial: Dari Klasik Hingga Postmodern. Yogyakarta: Ar Ruzz Media. View in (Google Scholar)

17) Rapar, J. H. (1996). Pustaka Filsafat Pengantar Filsafat. Kanisius.

View in (Google Scholar)

18) Heryanto, A. (Ed.). (2012). Budaya populer di Indonesia: mencairnya identitas pasca-orde baru. Jalasutra. View in (Google Scholar)

19) Husserl, E. (1977). Cartesian meditations: An introduction to metaphysics (D. Cairns, Trans.). The Hague: Martinus Nijhoff.

View in (Google Scholar)

20) Ibrahim, I. S. (2011). Kritik budaya komunikasi: budaya, media, dan gaya hidup dalam proses demokratisasi di Indonesia. Jalasutra.

View in (Google Scholar)

21) Kuntowijoyo, \& Ibrahim, I. S. (2004). Lifestyle ecstasy: kebudayaan pop dalam masyarakat komoditas indonesia. Jalasutra: Forum Indonesia untuk Komunikasi Tanpa Kekerasan (Fiskontak).

View in (Google Scholar)

22) Ihalauw, J. J. (2008). Konstruksi Teori: Komponen dan Proses. Jakarta: PT Gramedia Widiasarana Indonesia.

View in (Google Scholar)

23) Juni, Ngakan Ketut. (2016). Manfaat Bhujangasana bagi Kesehatan Reproduksi: Prosiding Seminar Nasional Kemanfaatan Latihan Fisik dalam Meningkatkan Kesehatan Jasmani dan Rohani Menuju Kesempurnaan Hidup. Denpasar: IHDN.

View in (Google)

24) Kotler, P. (2002). Manajemen Pemasaran Edisi Milenium. Jakarta: PT. Prenhallindo.

View in (Google Scholar)

25) Krisna, Anand. (2002). Tantra Yoga. Jakarta: Gramedia.

View in (Google)

26) Krishna, A. (2015). Yoga Sutra Patanjali Bagi Orang Modern. Gramedia Pustaka Utama.

View in (Google Scholar)

27) Kuntowijoyo. (1987). Budaya dan masyarakat. Tiara Wacana Yogya.

View in (Google Scholar)

28) Yasa, I., \& Suka, W. (2011). Yoga Marga Rahayu. Denpasar: Lemlit Universitas Hindu Indonesia.

View in (Google Scholar)

29) Lubis, A. Y. (2014). Filsafat Ilmu Klasik Hingga Kontemporer. Jakarta: Raja Grafindo Persada.

View in (Google Scholar) 
30) Lubis, A. Y. (2014). Postmodernisme: teori dan metode. Jakarta: Rajawali Pers.

View in (Google Scholar)

31) Martono, Nanang. 2014. Sosiologi Perubahan Sosial. Jakarta: RajaGrafindo Persada.

View in (Google Scholar)

32) Maswinara, I Wayan. 1999. Sistem Filsafat Hindu: Yayasan Sanatana Dharma, Surabaya: Paramita. View in (Google Scholar)

33) Maswinara. 2006. "Sistem Filsafat Hindu (Sarva Darsana Samgraha). Surabaya: Paramita. View in (Google Scholar)

34) Matius, Ali. 2010. Filsafat India, Tangerang: Sanggar Luxor.

View in (Google Scholar)

35) Mowen, Jhon C., Minor, M. 2002. Perilaku Konsumen. Jakarta: Erlangga.

View in (Google Scholar)

36) Musli, Muhammad. 2004. Filsafat Ilmu. Yogyakarta: Belukar.

View in (Google Scholar)

37) Nasikum, 1995. Sistem Sosial Indonesia. Jakarta: PT Raja Grafindo Persada.

View in (Google Scholar)

38) Moleong, L. J. (1999). Metodologi penelitian. Bandung: PT. Remaja Rosda Karya.

View in (Google Scholar)

39) Nasution, S. (2003). Metode Research (penelitian ilmiah). Jakarta: Bumi Aksara.

View in (Google Scholar)

40) Piliang, Y. A., \& yang Berlari, D. (2004). Mencari Tuhan-Tuhan Digital. Grasindo, Jakarta, Jakarta, 153.

View in (Google Scholar)

41) Piliang, Y. A. (2011). Dunia yang dilipat: Tamasya melampaui batas-batas kebudayaan. Matahari.

View in (Google Scholar)

42) Piliang Amir, Yasraf. (2006)." Imagologi dan Lifestyle". Dalam Resistensi Lifestyle, Teori dan Realitas. Editor Alfathri Aldin. Yogyakarta dan Bandung: Jalasutra.

View in (Google)

43) Raditya, Ardie. 2014. Sosiologi Tubuh, Membentang Teori di Ranah Aplikasi. Yogyakarta : Kaukaba Dirgantara.

View in (Google Scholar)

44) Nyoman, K. R. (2004). Teori, Metode, dan Teknik Penelitian Sastra.

View in (Google Scholar)

45) Ritzer, G. Doglas JG (2004). Teori Sosiologi Modern. Jakarta: Kencana Prenada Media Group.

View in (Google Scholar)

46) Purwanto, E. (2011). Makna Konseptual Berimplikasi Politis Pada Lirik Lagu Slank Album Mata Hati Reformasi (Doctoral dissertation, Universitas Negeri Semarang).

View in (Google Scholar)

Malini, K., Yasa, I., \& Utama, I. (2018). Yoga as lifestyle of postmodern society in Bintaro Jaya. International Journal Of Social Sciences And Humanities (IJSSH), 2(2), 1-14. doi:10.29332/ijssh.v2n2.112 
47) Rudia, Adipura dkk. (1990). Tatwa Darsana. Jakarta: IPEBI.

View in (Google)

48) Samiti, Kaivalyadhama S.M.Y.M. (1997). Gheranda Samhita. India: Mahasviaratri.

View in (Google)

49) Sarasvati, Svami Satyananda. (2002). Asana, Pranayama, Mudra, Bandha. Surabaya: Paramita.

View in (Google)

50) Sarasvati, Svami Satyananda. (2002). Surya Namaskara. Surabaya: Paramita.

View in (Google)

51) Saraswati, Swami Satya Prakas. (1996). Patanjali Raja Yoga. Surabaya: Paramita.

View in (Google)

52) Shanty, Sandra \& Yuliani, Kenuk. (2014). The Power of Yoga. Yogyakarta: CV Solusi Distribusi.

View in (Google)

53) Sindhu, P. (2015). Panduan lengkap yoga: untuk hidup sehat dan seimbang. Mizan Qanita.

View in (Google Scholar)

54) Somvir. (2016). Yoga: Prosiding Seminar Nasional Kemanfaatan Latihan Fisik dalam Meningkatkan Kesehatan Jasmani dan Rohani Menuju Kesempurnaan Hidup. Denpasar: IHDN.

View in (Google)

55) Storey, J. (2003). Teori budaya dan budaya pop: memetakan lanskap konseptual cultural studies. Penerbit Qalam.

View in (Google Scholar)

56) Strinati, Dominic. (2016). Popular Culture Pengantar Menuju Teori Budaya Populer. Yogyakarta: Narasi. View in (Google Scholar)

57) Suamba, Putu. 2015. Yoga Sutra Patanjali Terjemahan Sanskerta-Indonesia. Denpasar: Widya Dharma Unhi.

View in (Google)

58) Sudiarja, A. (2006). Agama (di zaman) yang berubah. Kanisius.

View in (Google Scholar)

59) Sugata, I Made. (2016). Hubungan Yoga dan Kesehatan: Prosiding Seminar Nasional Kemanfaatan Latihan Fisik dalam Meningkatkan Kesehatan Jasmani dan Rohani Menuju Kesempurnaan Hidup. Denpasar: IHDN. View in (Google)

60) Sugihartati, R. (2014). Perkembangan masyarakat informasi \& teori sosial kontemporer. Kencana. View in (Google Scholar)

61) Surada, I Made. (2016). Ajaran Yoga dalam Agama Hindu: Prosiding Seminar Nasional Kemanfaatan Latihan Fisik Dalam Meningkatkan Kesehatan Jasmani dan Rohani Menuju Kesempurnaan Hidup. Denpasar : IHDN.

View in (Google) 
62) Suwantana, I Gede. (2016). Perkembangan Yoga di Seluruh Dunia: Prosiding Seminar Nasional Kemanfaatan Latihan Fisik dalam Meningkatkan Kesehatan Jasmani dan Rohani Menuju Kesempurnaan Hidup. Denpasar: IHDN.

View in (Google Scholar)

63) Sztompka, P., Alimandan, \& Santoso, T. B. (2004). Sosiologi perubahan sosial. Prenada Media.

View in (Google Scholar)

64) Sugiarto, R., \& Pudja, G. (1982). Swetaswatara Upanishad. Departemen Agama, RI.

View in (Google Scholar)

65) Udayana, Agus Indra. (2016). Yoga : Antara Kesehatan dan Bisnis: Prosiding Seminar Nasional Kemanfaatan Latihan Fisik dalam Meningkatkan Kesehatan Jasmani dan Rohani Menuju Kesempurnaan Hidup. Denpasar: IHDN.

View in (Google)

66) Utama, I Wayan Budi. (2016). Yoga sebagai Lifestyle. Denpasar: Unhi.

View in (Google )

67) Matutino, C. L. T. (2016). Mistik Ketimuran: Perjumpaan Hinduisme dengan Penghayatan Kebatinan dalam Budaya Jawa. Deepublish.

View in (Google Scholar)

68) Vivian, J. (2008). Teori komunikasi massa. Jakarta: Kencana.

View in (Google Scholar)

69) Wariati, Ni Luh Gede. (2016). Manfaat Surya Namaskara bagi Tubuh dan Jiwa: Prosiding Seminar Nasional Kemanfaatan Latihan Fisik dalam Meningkatkan Kesehatan Jasmani dan Rohani Menuju Kesempurnaan Hidup. Denpasar: IHDN.

View in (Google)

70) Candrawan, I. B. G. (2017). Kosmologis Masyarakat Hindu Di Kawasan Tri Danu Dalam Pelestarian Lingkungan Hidup. Jurnal Ilmu Agama Dan Kebudayaan, 14(27).

View in (Google Scholar)

71) Kusumayanti, G. D., \& Dewantari, N. M. (2017). The Influence of Low Purine Diet and Physical Activity on Changing of Uric Acid Levels in Hyperuricemia. International Journal of Health Sciences (IJHS), 1(3), 1-9.

View in (Google Scholar)

72) Wirawan, I. G. B. (2018). Surya Namaskara Benefits for Physical Health. International Journal of Social Sciences and Humanities (IJSSH), 2(1), 43-55.

View in (Google Scholar)

73) Wisudawati, N. N. S., \& Maheswari, A. I. A. (2018). Potential of Silver Craft Product through to Community-Based for Tourism Sustainability in Celuk Village. International Research Journal of Management, IT and Social Sciences (IRJMIS), 5(1), 9-15.

View in (Google Scholar)

Malini, K., Yasa, I., \& Utama, I. (2018). Yoga as lifestyle of postmodern society in Bintaro Jaya. International Journal Of Social Sciences And Humanities (IJSSH), 2(2), 1-14. doi:10.29332/ijssh.v2n2.112 


\section{Biography of Authors}

\begin{tabular}{|l|l||}
\hline & $\begin{array}{l}\text { Kadek Hema Malini was born in Seririt, May 7th, 1975. She is lecturer at STA } \\
\text { Dharma Nusantara Jakarta. } \\
\text { Email: kadekhema@gmail.com }\end{array}$ \\
\hline
\end{tabular}

